\title{
Tax blow leaves Australian science reeling
}

\section{Peter Pockley, Canberra}

The Australian government has slipped a cut to research grants into the fine print of its latest budget, delivered on 9 May. Australian researchers have learnt that they are expected to aid the government in making 'savings' of hundreds of millions of dollars.

The impact of a controversial new goods and services tax (GST), being introduced in July, emerged only when organizations received letters from ministers, which Nature has obtained, after the budget was presented.

Minister for Industry, Science and Resources, Nick Minchin, wrote that this year the normally reliable budget figures are "indicative only".

The budget plans "will require adjustment to the funding allocation of a large number of programmes", he added. Minchin's department has lost A \$104 million (US\$60 million), possibly because of the new tax, and is moving to pass this on to grantees.

The government argues that financial modelling shows that recipients would have received a 'windfall' from the GST, compared to the other taxes that it will replace.

The letters do not specify the proportion to be cut from each grant. But the news that

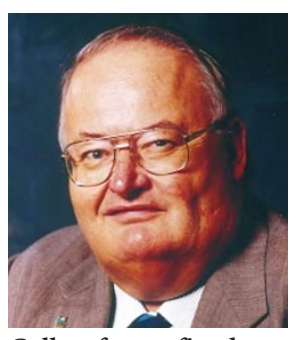

Cullen: faces a fiscal

"triple whammy".
Commonwealth Scientific and Industrial Research Organisation. Its budget would fall 3.4 per cent in real terms, to $\mathbf{A} \mathbf{6 1 6}$ million.

The 65 Cooperative Research Centres (CRCs) are deeply worried about their government grants, which average $\mathrm{A} \$ 2$ million. Most of their money goes on salaries or is passed through universities, both of which are free of a GST imposition.

Peter Cullen, director of the CRC for Freshwater Ecology in Canberra, says the centres face a "triple whammy" consisting of the GST, the extra costs of administering it, and annual cuts of 1 per cent. He believes that costs for the CRCs are likely to increase with the GST, with no provision for compensation.
The government is not commenting, but the Labor opposition will press ministers for figures when parliamentary committees resume next week. The row has overshadowed the government's increase in support for R\&D. A rise in funding for medical research and tax concessions for business R\&D are estimated to boost expenditure by 1.1 per cent in real terms, to A \$4.5 billion (see Nature 399, 94; 1999).

In charting the year ahead, Treasurer Peter Costello made no mention of $R \& D$, the only new programme being modest support for commercialization of biotechnology (A\$30.5 million over four years). This failed to quell a chorus of complaint from academic and research leaders over the continuing neglect of universities (see Nature 382, 659; 1996).

The annual statement on R\&D funding revealed a decline in government support to 0.68 per cent of gross domestic product. Australian business spending on R\&D ranks seventeenth out of 20 industrialized nations.

The effect of the new GST on grants to university-based researchers remains so unclear that applicants have been required to submit two budgets with and without adjustments for it. 